\title{
Using Deferred Income Taxes As A Link Between Intermediate Accounting And Corporate Income Tax Courses
}

Robert P. Derstine, Ph.D., CPA, Kutztown University, USA

David D. Wagaman, CPA, Kutztown University, USA

\begin{abstract}
The accounting curriculum (in fact business colleges in general) often is accused of operating in silos. As a result, it is claimed that students fail to see the connections among the assignments in their separate course work and the necessity to have an integrated understanding to function effectively in the real-world. As a response to the criticism, we use deferred income taxes as a means to help students bridge the gap between their Intermediate Accounting classes and their Corporate Income Tax course. As a bonus, students also: 1.) better understand the difficult topic of deferred income taxes, 2.) better understand Schedule M-1on the corporate tax return, and 3.) gain experience in documentation via the preparation of accounting work papers.
\end{abstract}

Keywords: Deferred Income Tax; Intermediate Accounting; Corporate Income Tax Course

\section{INTRODUCTION}

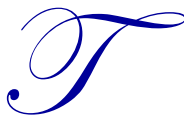

o help overcome the tendency of students to view each course in isolation, the following illustration shows how the topic of deferred income taxes can help students integrate Intermediate Accounting and Corporate Income Tax courses. Students also should better understand the difficult topic of deferred income taxes, better understand Schedule M-1 on the corporate tax return, and gain experience in documentation via the preparation of accounting work papers.

\section{DATA FOR THE ILLUSTRATION}

The information below is limited to three temporary differences and one permanent difference. The list of differences easily can be expanded by the instructor to include as many as deemed appropriate.

\begin{tabular}{|c|c|c|c|c|c|}
\hline \multicolumn{3}{|c|}{ Net Book Value at $12 / 31 / 20 X 9$} & \multicolumn{3}{|c|}{ Tax Basis at $12 / 31 / 20 \mathrm{X} 9$} \\
\hline & Accounts Receivable, less Allowance & $\$ 225,000$ & \multicolumn{2}{|c|}{ Accts. Rec. (no Allowance) } & $\$ 340,000$ \\
\hline 2) & Trading Securities, market & 46,000 & \multicolumn{2}{|c|}{ Trading Securities, cost } & 28,000 \\
\hline 3) & $\begin{array}{l}\text { Trucks less Accumulated Depreciation } \\
\text { using Straight-Line }\end{array}$ & 85,000 & \multicolumn{2}{|c|}{$\begin{array}{l}\text { Trucks less Accumulated } \\
\text { using MACRS }\end{array}$} & 61,000 \\
\hline & er Information: & \multicolumn{2}{|c|}{ 20X9 Income Statement } & \multicolumn{2}{|c|}{ 20X9 Tax Return } \\
\hline & Debts Expense & \multicolumn{2}{|c|}{$\$ 90,000$} & \multicolumn{2}{|l|}{$\$ 50,000$} \\
\hline & ealized Gain on Trading Securities & \multicolumn{2}{|c|}{10,000} & \multicolumn{2}{|l|}{$-0-$} \\
\hline & reciation Expense & \multicolumn{2}{|c|}{48,000} & \multicolumn{2}{|l|}{53,000} \\
\hline & dends from Trading Securities & \multicolumn{2}{|c|}{3,000} & \multicolumn{2}{|l|}{900} \\
\hline & $\mathrm{k}$ Income Before Taxes for $20 \mathrm{X} 9$ & \multicolumn{2}{|c|}{900,000} & & \\
\hline
\end{tabular}

\section{ACCOUNTING WORK PAPERS}

Students frequently present their answers to accounting and tax assignments in the form of a typed word document, a spreadsheet, or hand-written on a piece of notebook paper. Requiring students to present their answers 
using accounting work paper format similar to that shown in Tables 1 and 2 should be more acceptable in the workplace and will help the students understand some of the complexities of accounting for income taxes.

The Deferred Income Tax Work paper (Table 1) uses the "balance sheet approach" to determine in the last column to the right the $\$ 10,500$ to be debited to the Deferred Income Tax — Current Asset account and the $\$ 1,750$ to be credited to the Deferred Income Tax-Long-Term Liability account as part of the income tax journal entry for 20X9. Note the "Book vs. Tax Difference at 12/31/X9" column on the Deferred Income Tax Work paper is designed to tie into the deferred tax account balances on the 20X9 balance sheet.

Table 1: Deferred Income Tax Work paper

\begin{tabular}{|c|c|c|c|c|c|c|}
\hline $\begin{array}{c}\text { Balance } \\
\text { Sheet } \\
\text { Accounts }\end{array}$ & $\begin{array}{c}\text { 12/31/X9 } \\
\text { Book } \\
\text { Value }\end{array}$ & $\begin{array}{c}\text { 12/31/X9 } \\
\text { Tax } \\
\text { Basis }\end{array}$ & $\begin{array}{c}\text { Book } \\
\text { vs. } \\
\text { Tax } \\
\text { Difference } \\
\text { at } \\
\text { 12/31/X9 } \\
\end{array}$ & $\begin{array}{c}\text { Assumed } \\
\text { Book } \\
\text { vs. } \\
\text { Tax } \\
\text { Difference } \\
\text { at } \\
\text { 12/31/X8 }\end{array}$ & $\begin{array}{l}\text { Change } \\
\text { in } \\
\text { Difference } \\
\text { During } \\
20 \times 9\end{array}$ & $\begin{array}{c}\text { Change } \\
\text { Needed to } \\
\text { DIT account } \\
\text { (Change } \\
\text { times } \\
\text { 35\% tax } \\
\text { rate) }\end{array}$ \\
\hline \multicolumn{7}{|l|}{ Current: } \\
\hline Accounts Rec. & $\$ 225,000$ & $\$ 340,000$ & $(\$ 115,000)$ & $(\$ 75,000)$ & $(40,000)^{*}$ & $(\$ 14,000)$ \\
\hline \multirow[t]{4}{*}{ Trading Portfolio } & 46,000 & 28,000 & 18,000 & 8,000 & $\underline{10,000}$ & 3,500 \\
\hline & & & $(97,000)$ & & 30,000 & $(\$ 10,500) * *$ \\
\hline & & & $\times 35 \%$ & & & \\
\hline & & 20X9 Bal. Sheet & $\$ 33,950$ & & & \\
\hline \multicolumn{7}{|l|}{ Long-Term: } \\
\hline \multirow[t]{3}{*}{ Truck } & 85,000 & 61,000 & 24,000 & 19,000 & 5,000 & $\$ 1,750 * * *$ \\
\hline & & & $\mathrm{x} 35 \%$ & & & \\
\hline & & 20X9 Bal. Sheet & "\$8,400 & & & \\
\hline \multicolumn{7}{|c|}{$* \$ 40,000$ amount in parentheses indicates taxable income will be higher than book income for $20 X 9$} \\
\hline \multicolumn{7}{|c|}{$* * \$ 10,500$ amount in parentheses indicates debit to the Deferred Income Tax-Current Asset account } \\
\hline
\end{tabular}

The instructor has the option to supplement Table 1 with an illustration of the "income statement approach" to determine the 20X9 entries to the deferred income tax accounts. The income statement approach would multiply the temporary differences shown above between the 20X9 income statement amount and the 20X9 tax return amount by the statutory income tax rate to get the 20X9 entries to the deferred income tax accounts.

The Tax Accrual Work paper (Table 2) provides the calculation supporting the $\$ 323,015$ credit to Income Tax Payable in the 20X9 income tax journal entry. The design of this work paper also allows a direct calculation of the $\$ 314,265$ debit to Income Tax Expense. (With a permanent difference existing for 20X9, simply multiplying the $\$ 900,000$ book income before tax times the 35\% income tax rate would yield an incorrect amount for Income Tax Expense).

Table 2: Tax Accrual Work paper

\begin{tabular}{|l|c|}
\hline Book Income Before Taxes for 20X9 & $\$ 900,000$ \\
\hline Permanent Difference: Special Dividend Received Deduction-70\% of \$3,000 Dividends & $(2,100)$ \\
\hline Basis for Calculating Income Tax Expense for 20X9 (35\% x \$897,900=\$314,265) & $\$ 897,900$ \\
\hline $\begin{array}{l}\text { Temporary Differences: } \\
\text { Excess of Estimated Bad Debts Expense vs. Accts. Receivable Direct Write-off for 20X9 }\end{array}$ & 40,000 \\
\hline Unrealized Gain on Marking to Market the Trading Portfolio on December 31, 20X9 & $(10,000)$ \\
\hline Excess of MACRS Depreciation vs. Straight-Line Depreciation for 20X9 & $(5,000)$ \\
\hline Taxable Income & $\$ 922,900$ \\
\hline Statutory Income Tax Rate & $\mathbf{x} .35$ \\
\hline Income Tax Payable & $\$ 323,015$ \\
\hline
\end{tabular}




\section{JOURNAL ENTRY FOR INCOME TAXES}

The Deferred Income Tax Work paper (Table 1) provides the dollar amounts for the Deferred Income Tax accounts in the 20X9 income tax journal entry. The Tax Accrual Work paper (Table 2) provides the dollar amount for Income Taxes Payable and proves the "plug" to Income Tax Expense is correct.

Income Tax Journal Entry for 20X9

\begin{tabular}{|c|c|c|}
\hline & Debit & Credit \\
\hline Income Tax Expense ("Plug"-also directly calculated in Table 2) & 314,265 & \\
\hline Deferred Income Tax —Current Asset (from Table 1) & 10,500 & \\
\hline Deferred Income Tax Payable-Long-Term Liability (from Table 1) & & 1,750 \\
\hline Income Tax Payable (from Table 2) & & 323,015 \\
\hline
\end{tabular}

The \$10,500 debit is to a Current Deferred Income Tax Asset account because both Accounts Receivable and the Trading Portfolio are classified as current accounts on the Balance Sheet. The $\$ 1,750$ credit is to a LongTerm Deferred Income Tax Liability account because Trucks are classified as a non-current account on the Balance Sheet.

\section{SCHEDULE M-1 ON CORPORATE TAX RETURN}

Using the previously illustrated accounting work papers and income tax journal entry developed in the Intermediate Accounting course, students can see the integration of deferred income taxes into the Corporate Income Tax course by requiring students to complete Schedule M-1 (Table 3) of the Corporate Income Tax Form 1120. (For companies with more than $\$ 10$ million in assets, Schedule M-3 would be completed instead of Schedule M-1.)

Table 3: Schedule M-1

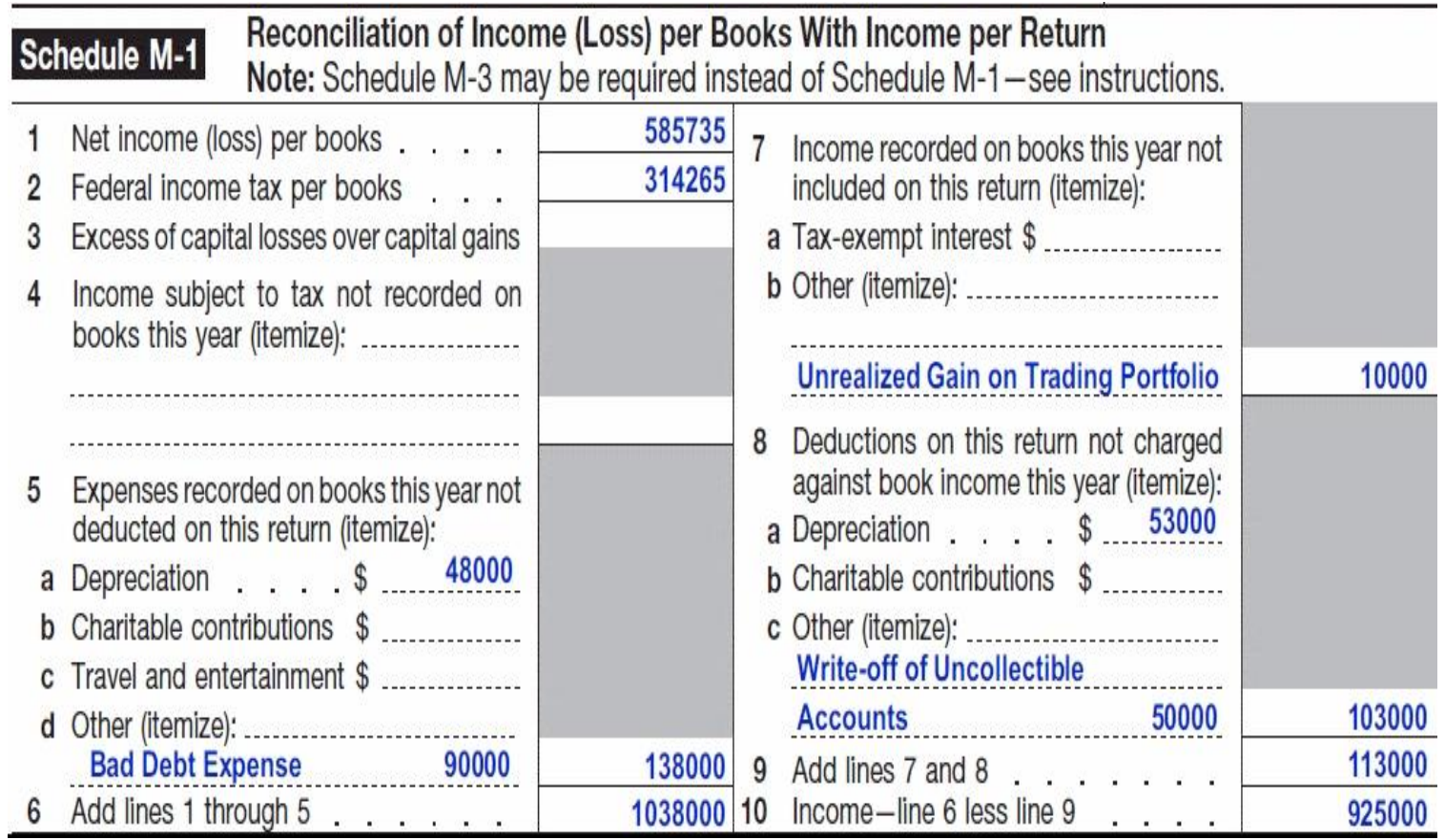

The $\$ 925,000$ "Income" on line 10 of Schedule M-1 would be the Taxable Income before Special Deductions. Subtracting the $\$ 2,100(\$ 3,000 \times 70 \%)$ permanent difference created by the Special Dividend Received Deduction for the Trading Portfolio Dividends from the $\$ 925,000$ would equal the $\$ 922,900$ Taxable Income shown on the Tax Accrual Work paper (Table 2). 


\section{CONCLUSION/EXTENSIONS}

Deferred Income Taxes can provide more than just an example of a topic that helps students appreciate the integration between Intermediate Accounting and Corporate Income Tax courses. The illustration can be enhanced by requiring preparation of the complete Corporate 1120 Tax Return. The Auditing course could be added to the deferred income tax example by requiring students to turn the accountant's worksheets used in the illustration into audit work papers and/or requiring students to draft the Income Tax Note Disclosure-including determination of the effective tax rate for 20X9. Other extensions could include requiring students to research the topic of deferred income taxes in the accounting and tax literature. Requiring students to provide a written synopsis of their research findings adds communication to the skills list that can be enhanced.

\section{AUTHOR INFORMATION}

Robert P. Derstine, Ph.D., CPA, is a professor of accounting at Kutztown University. Professor Derstine has been awarded the Lindback and Dougherty Teaching Excellence Awards from Villanova University. His publications include articles in the Journal of Accounting Research, Accounting Review, The CPA Journal, Pennsylvania CPA Journal, Accounting Instructors' Report, and the New Accountant. E-mail: derstine @ kutztown.edu (Corresponding author)

David D. Wagaman, Masters of Taxation, CPA, is an associate professor of accounting at Kutztown University. Professor Wagaman is a recipient of Kutztown University's Arthur and Isabel Wiesenberger Faculty Award for Excellence in Teaching. He has published in the Pennsylvania CPA Journal, New Accountant, and the Journal of Accounting and Finance. Professor Wagaman currently serves as a member of the Pennsylvania CPA Journal Editorial Board. E-mail: dwagaman@kutztown.edu 